\title{
A STUDY OF TOTAL SIALIC ACID AND LIPID BOUND SIALIC ACID LEVELS AND TOTAL SIALIC ACID TO TOTAL PROTEIN RATIO IN CANCER PATIENTS
}

\author{
Sarat Chandan Tummalacharla1, Gonella Geetha Meenakshi² \\ ${ }^{1}$ Consultant Biochemist, Vijaya Diagnostics, Hyderabad. \\ ${ }^{2}$ Associate Professor, Department of Biochemistry, Kakatiya Medical College, Warangal.
}

\begin{tabular}{l} 
ABSTRACT \\
\hline BACKGROUND \\
Cancers are characterised by unregulated cell growth, tissue invasion, and metastasis. Biological markers can be used to monitor \\
cancer, predict the therapeutic response and prognosis of cancer, and in certain situations even to diagnose cancer. These markers \\
are referred to as tumour markers. Aberrant glycosylation processes in tumour cells may contribute to the biosynthesis of the \\
carbohydrate structures so that malignant or transformed cells contain increased levels of SA on their surfaces. \\
The aim of the present study was to evaluate the usefulness of serum sialic acid in early diagnosis of cancers as a tumour marker \\
for various cancers and to evaluate the usefulness of sialic acid as an indicator for severity of the disease for staging and metastasis.
\end{tabular}

\section{MATERIALS AND METHODS}

A case control study was done with 120 patients divided into 4 groups (healthy controls, pathological controls, cancer without metastasis, cancer with metastasis) with inclusion and exclusion criteria. Serum samples were collected and total sialic acid, lipid bound sialic acid and total proteins were measured. Total sialic acid/Total protein ratio was calculated. Multiple comparisons between different groups were done using ANOVA test.

\section{RESULTS}

Data analysis indicated a significant increase $(\mathrm{p}<0.0001)$ in the TSA, LBSA and TSA/TP ratio in cancer patients without metastasis $(92.97 \pm 3.499 \mathrm{mg} / \mathrm{dL}, 31.50 \pm 2.596 \mathrm{mg} / \mathrm{dL}$ and $15.35 \pm 1.101 \mathrm{mg} / \mathrm{g})$ and cancer patients with metastasis $(105.5 \pm 4.725 \mathrm{mg} / \mathrm{dL}$, $39.17 \pm 4.136$ and $18.98 \pm 1.587 \mathrm{mg} / \mathrm{g})$ as compared to pathological controls $(80.27 \pm 3.473 \mathrm{mg} / \mathrm{dL}, 30.70 \pm 2.902 \mathrm{mg} / \mathrm{dL}$ and 11.34 $\pm 0.863 \mathrm{mg} / \mathrm{g}$ ) and healthy controls ( $51.67 \pm 6.065 \mathrm{mg} / \mathrm{dL}, 17.80 \pm 3.671$ and $7.233 \pm 1.012 \mathrm{mg} / \mathrm{g}$ ) respectively. A significant decrease $(\mathrm{p}<0.0001)$ in serum levels of total proteins were found in all cases of cancer without metastasis and with metastasis $(6.153 \pm 0.231$ $\mathrm{mg} / \mathrm{dL}$ and $5.577 \pm 0.281 \mathrm{~g} / \mathrm{dL})$ as compared with pathological controls and healthy controls $(7.103 \pm 0.457 \mathrm{~g} / \mathrm{dL}$ and $7.157 \pm 0.512)$.

\section{CONCLUSION}

There is a significant increase in TSA and TSA/TP as malignant diseases progress, suggesting that these markers may be useful in monitoring or therapeutic interventions and disease progression.

\section{KEYWORDS}

Lipid bound, Sialic Acid.

HOW TO CITE THIS ARTICLE: Tummalacharla SC, Meenakshi GG. A study of total sialic acid and lipid bound sialic acid levels and total sialic acid to total protein ratio in cancer patients. J. Evolution Med. Dent. Sci. 2017;6(22):1778-1783, DOI: $10.14260 /$ jemds/2017/391

\section{INTRODUCTION}

Cancer has become a big threat among the various diseases to human beings globally. Cancer is the second most common disease in India responsible for maximum mortality with about 0.3 million deaths per year. This is owing to the poor availability of prevention, diagnosis and treatment of the disease. All types of cancers have been reported in Indian population including the cancers of skin, lungs, breast, rectum, stomach, prostate, liver, cervix, oesophagus, bladder, blood, mouth. The causes of such high incidence of these cancers may be both internal (genetic, mutations, hormonal, poor immune

Financial or Other, Competing Interest: None.

Submission 28-06-2016, Peer Review 31-08-2016,

Acceptance 15-09-2016, Published 16-03-2017.

Corresponding Author:

Gonella Geetha Meenakshi,

H. No. 1-10-155, Road No. $8 \mathrm{H}$

Dwarakapruam Colony,

Dilsukhnagar, Hyderabad,

Telangana State.

E-mail: amadhuratc@gmail.com

DOI: $10.14260 /$ jemds $/ 2017 / 391$ conditions) and external or environmental factors (food habits, industrialisation, overgrowth of population, social etc.). ${ }^{1}$

\section{Aims of the Study}

1. The main purpose of the present study was to evaluate the usefulness of serum sialic acid in clinical diagnostics.

2. To evaluate the usefulness of sialic acid as a tumour marker.

3. To evaluate the usefulness of sialic acid as an indicator for severity of the disease.

Biological markers can be used to monitor cancer, predict the therapeutic response and prognosis of cancer, and in certain situations even diagnose cancer. These markers, referred to as tumour markers, are naturally occurring or modified molecules that can be measured in serum, plasma, or other body fluids and their concentration changes in the presence of cancer. ${ }^{2}$

Before a tumour marker can be used in routine clinical diagnostics a massive amount of work is needed. After discovery of a promising marker, an assay system has to be 
developed and a thorough clinical evaluation has to be carried out. $^{3}$

From over 30 acetylated derivatives of neuraminic acid, $\mathrm{N}$ acetylneuraminic acid (referred to as sialic acid) is the most common in humans. ${ }^{4}$ Aberrant glycosylation processes in tumour cells may contribute to the biosynthesis of the carbohydrate structures so that malignant or transformed cells contain increased levels of SA on their surfaces. Cell shape, anchorage and growth rate have been shown to influence the SA content of the cell. ${ }^{5}$ In some studies, the total sialic acid content has been observed to increase in highly metastatic cells compared with nonmetastatic cells.6, 7 However, in other studies no consistent increase in total cellular sialic acid has been found, but highly metastatic cells have been observed to have significantly elevated amounts of neuraminidase-releasable SA and also an increased degree of sialylation of galactose and $\mathrm{N}$-acetylgalactosamine groups compared with non-metastatic cells.8,9

This study of sialic acid was taken up in cancers (metastasis) to observe the importance of sialic acid as a biomarker to monitor prognosis and predict severity.

\section{MATERIALS AND METHODS}

\section{Setting}

A case control study was conducted in the Department of Biochemistry, Osmania General Hospital, Hyderabad.

\section{Sources of samples and Data}

Department of Biochemistry, Osmania General Hospital, Hyderabad, MNJ Cancer Hospital, Redhills, Hyderabad.

\section{Controls}

Controls were healthy normal men and women of age group 18-60.

\section{Pathological controls (nonmalignant diseases)}

Patients with liver diseases, diabetes, intestinal disorders

\section{Cases}

The patients with cancer came to the Osmania General Hospital and MNJ Cancer Hospital. The cases are divided into two groups.

\section{Cases without Metastasis}

30 cancer cases without metastasis were taken. The age group of patients is between 18-79 of which 23 were female and 7 were male. 15 females had breast cancer, 5 females suffered with cervical cancer, 3 females with ovarian cancer. Out of 7 males, 4 males had oral cancer, 2 males had ALL, 1 male had lung cancer.

\section{Cases with Metastasis}

30 cancer cases with metastasis were taken. The age group of patients is between 18-78 of which 21 were female and 9 were male. Out of 21 females, 15 had breast cancer, 3 had cervical cancer, 2 had ovarian cancer, 1 had colon cancer. Out of 9 males, 3 were suffering with oral cancer, 3 were suffering with lung cancer, 2 had prostate cancer, 1 had colon cancer. The metastasis was to the liver, bones.

\section{Inclusion Criteria}

Cases with all cancers and with any stage of the disease were included.

\section{Exclusion Criteria}

Cancer patients with comorbid diseases like infections, diabetes, alcoholic liver diseases were excluded.

\section{Sample Collection}

$5 \mathrm{~mL}$ of venous blood was collected from all the study participants under aseptic conditions in a plain tube. Sample was centrifuged at $3000 \mathrm{rpm}$ for $10 \mathrm{~min}$. and serum was separated within two hours of collection of blood. Care was taken to prevent haemolysis of the samples.

\section{Materilas And Methods}

Estimation of Serum Sialic Acid/Modified Thiobarbituric Acid Assay Of Warren (Lorentz and Krass) ${ }^{10}$

Principle: Sialic acid is oxidised with sodium periodate in a concentrated phosphoric acid solution. The periodate oxidation product is coupled with thiobarbituric acid and resulting coloured solution is extracted into cyclohexanone.

- Normal range: $52-69 \mathrm{mg} / \mathrm{dL}$ or $1.58-2.22 \mathrm{mmol} / \mathrm{L}$.

- Storage: samples are stored at $-20^{\circ} \mathrm{C}$

- Stability: stable for six months at $-20^{\circ} \mathrm{C}$.

- Interfering substances: 2-deoxy-glucose, unsaturated fatty acids, lactose and maltose.

Estimation of Lipid Bound Sialic Acid by Katopodis and Coworkers Reagents 10

- Normal range: $13-26 \mathrm{mg} / \mathrm{dL}$ or $0.23-1.03 \mathrm{mmol} / \mathrm{L}$

- Storage: samples are stored at $-20^{\circ} \mathrm{C}$

- Stability: stable for six months at $-20^{\circ} \mathrm{C}$.

Estimation of Serum Total Proteins

Method: Biuret Method.

Reaction: End point assay.

Principle: Proteins react with copper sulphate wherein 'violet' coloured complex is formed between copper ions and $\mathrm{N}$ of peptide bond and $\mathrm{O}$ of water molecule. The violet coloured complex measured in a colorimeter at $540 \mathrm{~nm}$ against reagent blank.

Normal Range: 6-8 g\%

Stability: Tightly stoppered serum samples are stable for 1 week at room temperature and for 1 month at $2^{\circ} \mathrm{C}-4^{\circ} \mathrm{C}$.

\section{RESULTS}

The present study was undertaken in the Department of Biochemistry, Osmania Medical College, Osmania General Hospital and MNJ Cancer Hospital, Hyderabad.

A total of 120 patients were recruited for the study which included 30 healthy individuals, 30 pathologic controls (nonmalignant diseases), 30 cancer patients without metastasis and 30 with metastasis.

\section{The following parameters were analysed.}

1. Total sialic acid.

2. Lipid bound sialic acid.

3. Total proteins.

4. Total sialic acid/Total protein ratio.

The results were expressed in milligrams/decilitre for total sialic acid, lipid bound sialic acid, and grams/decilitre for total proteins. 
The data was analysed using GraphPad Prism software version 6.0.

Descriptive results are expressed as mean and SD of various parameters in different groups.

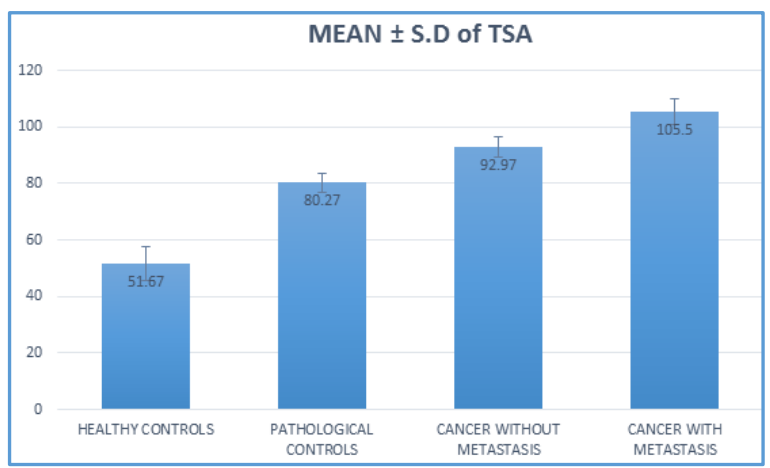

Figure 1: Graphical Representation of Mean \pm SD of Total Sialic Acid in Four Groups

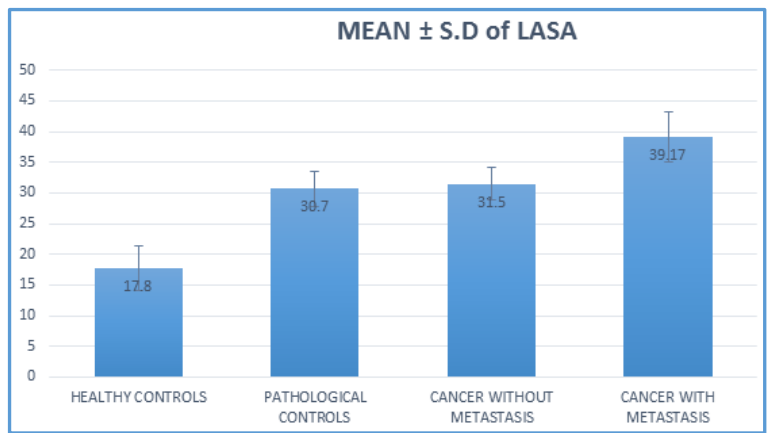

Figure 2: Graphical Representation of Mean \pm SD of Serum LBSA of Four Groups

\begin{tabular}{|c|c|c|c|}
\hline Parameter & F value & P value & $\mathbf{R}^{2}$ value \\
\hline TSA & 764.5 & $0.0001\left(^{* * * *}\right)$ & 0.9519 \\
\hline LBSA & 205.8 & $0.0001\left(^{* * * *}\right)$ & 0.8419 \\
\hline TP & 117.0 & $0.0001\left(^{* * * *}\right)$ & 0.7516 \\
\hline TSA/TP & 560.7 & $0.0001\left(^{* * * *}\right)$ & 0.9355 \\
\hline \multicolumn{2}{r}{} \\
\hline
\end{tabular}

Pearson's correlation was done to assess the correlation of parameters within each group.

\begin{tabular}{|c|c|c|c|c|c|}
\hline & & TSA & LBSA & TP & TSA/TP \\
\hline \multirow{2}{*}{ TSA } & Pearson's correlation & & 0.308 & -0.055 & 0.860 \\
\hline & Sig.(2-tailed) N & & 0.098 & 0.774 & 0.0001 \\
\hline \multirow{2}{*}{ LBSA } & Pearson's correlation & 0.308 & & -0.315 & 0.404 \\
\hline & Sig.(2-tailed) N & 0.098 & & 0.090 & 0.026 \\
\hline \multirow{2}{*}{ TP } & Pearson's correlation & -0.055 & -0.315 & & -0.546 \\
\hline & Sig.(2-tailed) N & 0.774 & 0.090 & & 0.002 \\
\hline \multirow{2}{*}{ TSA/TP } & Pearson's correlation & 0.860 & 0.404 & -0.546 & \\
\hline & Sig.(2-tailed) N & 0.0001 & 0.026 & 0.002 & \\
\hline
\end{tabular}

\begin{tabular}{|c|c|c|c|c|c|}
\hline & & TSA & LBSA & TP & TSA/TP \\
\hline \multirow{2}{*}{ TSA } & Pearson's correlation & & 0.025 & 0.043 & 0.531 \\
\hline & Sig.(2-tailed) N & & 0.894 & 0.822 & 0.003 \\
\hline \multirow{2}{*}{ LBSA } & Pearson's correlation & 0.025 & & -0.345 & 0.287 \\
\hline & Sig.(2-tailed) N & 0.894 & & 0.062 & 0.124 \\
\hline \multirow{2}{*}{ TP } & Pearson's correlation & 0.043 & -0.345 & & -0.821 \\
\hline & Sig.(2-tailed) N & 0.822 & 0.062 & & 0.0001 \\
\hline \multirow{2}{*}{ TSA/TP } & Pearson's correlation & 0.531 & 0.287 & -0.821 & \\
\hline & Sig.(2-tailed) N & 0.003 & 0.124 & 0.0001 & \\
\hline
\end{tabular}




\begin{tabular}{|l|l|l|l|l|l|}
\hline & & TSA & LBSA & TP & TSA/TP \\
\hline \multirow{2}{*}{ TSA } & Pearson's correlation & & -0.180 & -0.053 & 0.365 \\
\cline { 2 - 6 } & Sig.(2-tailed) N & & 0.340 & 0.781 & 0.048 \\
\hline \multirow{2}{*}{ LBSA } & Pearson's correlation & -0.180 & & -0.052 & 0.061 \\
\cline { 2 - 6 } & Sig.(2-tailed) N & 0.340 & & 0.786 & 0.749 \\
\hline \multirow{2}{*}{ TP } & Pearson's correlation & -0.053 & -0.052 & & -0.836 \\
\cline { 2 - 6 } & Sig.(2-tailed) N & 0.781 & 0.786 & & 0.0001 \\
\hline \multirow{2}{*}{ TSA/TP } & Pearson's correlation & 0.365 & 0.061 & -0.836 & \\
\cline { 2 - 6 } & Sig.(2-tailed) N & 0.048 & 0.749 & 0.0001 & \\
\hline
\end{tabular}

\begin{tabular}{|c|c|c|c|c|c|}
\hline & & TSA & LBSA & TP & TSA/TP \\
\hline \multirow{2}{*}{ TSA } & Pearson's correlation & & -0.160 & -0.510 & 0.854 \\
\hline & Sig.(2-tailed) N & & 0.399 & 0.004 & 0.0001 \\
\hline \multirow{2}{*}{ LBSA } & Pearson's correlation & -0.160 & & 0.042 & -0.120 \\
\hline & Sig.(2-tailed) N & 0.399 & & 0.826 & 0.528 \\
\hline \multirow{2}{*}{ TP } & Pearson's correlation & -0.510 & 0.042 & & -0.880 \\
\hline & Sig.(2-tailed) N & 0.004 & 0.826 & & 0.0001 \\
\hline \multirow{2}{*}{ TSA/TP } & Pearson's correlation & 0.854 & -0.120 & -0.880 & \\
\hline & Sig.(2-tailed) N & 0.0001 & 0.528 & 0.0001 & \\
\hline \multicolumn{6}{|c|}{ Table 5: Pearson's Correlation between Different Parameters in Cancer with Metastasis Group } \\
\hline
\end{tabular}

\section{DISCUSSION}

Cancer is a complex disease initiated by a series of cumulative genetic and epigenetic changes that occur in normal cells. However, in addition to the malignant cell itself, cancer is a disease of microenvironment and immunity. Although genetic and epigenetic alterations drive cellular transformation, genomic plasticity, and evolution, it has become increasingly apparent that multiple signals delivered within the tumour microenvironment by modifier genes, stromal, endothelial cells, and immune cells are critical factors in determining the progression vs. dormancy or destruction of an initiated lesion and also whether metastasis may occur. ${ }^{11}$ Tumorigenesis is a multistep process involving several mutations each of which results in discrete changes in the cellular metabolism. ${ }^{11}$

Sialic acids widely distributed in nature as terminal sugars in glycoproteins or glycolipids, impart a net negative charge to cell surface and are reported to be important in cell-to-cell and cell-to-matrix interactions. ${ }^{12,13}$

Increased sialylation helps malignant cells to disguise their immunogenic sites, to increase the negative charge of the outer cell membrane so that the binding and killing by lymphocytes and macrophages can be impaired and to hide the receptor site for IgM antibodies, which kill cells by a complement mediated reaction. 5,14

Cell activation, transformation and malignant growth increase the spontaneous shedding of cell surface components. 15 In growing cells, the rate of carbohydrate synthesis is significantly higher compared with non-growing cells. ${ }^{16}$

In cancer cells shedding is continuous and a rapidly ongoing phenomenon. 5 Since sialic acids are major constituents of glycoproteins and glycolipids, this study is concerned with TSA and/or LBSA levels.

In the present study, the mean \pm SD of total sialic acid in healthy controls is $51.67 \pm 6.065$, pathological controls is $80.27 \pm 3.473$, cancer without metastasis is $92.97 \pm 3.499$ and cancer with metastasis $105.5 \pm 4.725$. The increase was significant $(\mathrm{P}=0.0001)$. Rise in TSA levels could be attributed to malignant potential and changes in immunogenicity due to nonspecific changes. It may also reflect an increased amount of cellular destruction due to rapid tumour growth.

In other studies, the increase in total sialic acid levels are supported by Ryan et al and Silver et al. Serum TSA levels are significantly increased in malignant melanoma, and, these levels are directly related to tumour burden and disease recurrence. ${ }^{16,17}$

Silver et al stated that TSA levels are also correlated with tumour burden in ovarian carcinomas even though no such correlation was found for carcinoembryonic antigen. 18

Hogan-Ryan et al did a study on breast cancer. They have shown that serum sialic acid concentrations were raised in breast cancer and reflected tumour stage. One of 10 Stage I, 5 of 13 Stage II, 15 of 23 Stage III and 15 of 19 Stage IV had high levels. Mean sialic acid values in the sera of patients with metastatic disease were significantly higher than in controls' sera. Breast cancer (Stages I and II) had a mean sialic acid value not significantly different from the control mean. Patients with advanced localised disease (Stage III) had significantly raised mean sialic acid values. They found no significant correlation between serum sialic acid levels and serum CEA values $(\mathrm{P}<$ 0.5 ). This would indicate that CEA and sialic acid measure different parameters, e.g. CEA is an immunological marker and sialic acid may reflect serum sialoglycoprotein derived from sources additional to tumour-cell surface. A higher proportion of patients had raised sialic acid levels compared to raised serum CEA, in all stages of breast cancer, especially the earlier stages. Serum sialic acid was raised in $56 \%$ and serum CEA in $33 \%$ of all breast-cancer patients. In patients with distant metastases, serum sialic acid was raised in $79 \%$ compared to raised CEA in $68 \%$, whilst $17 / 19(80 \%)$ had either raised sialic acid or CEA. ${ }^{19}$

Pluckinsky et al stated that TSA was increased in both the cancer patient and pathologic control groups when compared to normal controls. When the cancer patients were grouped in terms of primary sites, significant increases in TSA were seen for the gastrointestinal, breast, pancreatic, and cholangiocarcinoma subgroups but not for the melanoma and rectal cancer patients. When the cancer patients were subdivided 
according to severity of disease, the highest levels of TSA were found for the most advanced stages of malignancy. ${ }^{20}$

In the present study, the mean \pm SD of lipid bound sialic acid in healthy controls is $17.80 \pm 3.671$, pathological controls is $30.70 \pm 2.902$, cancer without metastasis is $31.50 \pm 2.596$ and cancer with metastasis is $39.17 \pm 4.136$. The increase was significant $(\mathrm{p}=0.0001)$. This LBSA can be released into the serum through increased turnover, secretion and/or shedding, as the sialic acid is a part of glycolipids of the malignant cell surface.

The results are in support of other studies by Abdul Wahab et al. The elevation of LBSA has been reported in majority of children with leukaemia's in adults with acute myeloid leukaemia, chronic myeloid leukaemia, acute lymphoblastic, leukaemia, chronic lymphocytic leukaemia and lymphomas. ${ }^{21}$

In cervical cancers, the findings are supported by Baskaran et al. The levels of LBSA were found to be significantly elevated in all stages and gradually increased from stage I to III.22

Charushila Y. Kadam et al stated that the increased concentration of lipid-bound sialic acid were found to correlate with the presence and extent of malignant disease. A good correlation was found between circulating levels of LBSA in different stages of oral cancer patients suggesting that tissue turnover rates of both membrane glycolipid and glycoprotein were to the extent of malignant transformation. ${ }^{23}$

Patel et al reported their observation as LBSA values were significantly higher in the breast cancer group compared with the control group. There was also a statistically significant difference in LBSA between the benign and malignant breast tumour group. ${ }^{24}$

In the present study, the total sialic acid is normalised with total proteins, the mean \pm SD of the ratio of sialic acid/total proteins in healthy controls is $7.233 \pm 1.012$, pathological controls is $11.34 \pm 0.863$, cancer without metastasis is $15.35 \pm$ 1.101 , cancer with metastasis is $18.98 \pm 1.587$. The increase was significant $(p=0.0001)$. The TSA/TP is positively correlated which is statistically significant.

The TSA/TP is supported by other studies. Pushpa Durgawale et al in their study in different cancer patients showed a significant rise in TSA/TP ratio. Results of their investigation indicate that TSA/TP ratio seems to be the best tested markers. ${ }^{25}$

In Pluckinsky et al, TSA/TP were significantly increased. TSA/TP elevations were also seen in a number of the pathologic control subgroups (intestinal, breast, and regional enteritis), indicating the lack of specificity of these markers. When the cancer patients were subdivided according to severity of disease, the highest levels of TSA/TP were found for the most advanced stages of malignancy. ${ }^{20}$

Jarkko Romppanen in his study found significantly increased serum TSA/TP values in children with leukaemia, solid tumours and infections compared with healthy children. Malignancy with simultaneous infection increased the TSA/TP concentrations significantly more than infection alone. ${ }^{26}$

Dr. V. Sreeramulu et al did a study in breast cancers. The serum TSA/TP values are significantly increased in malignancies as compared to controls indicating altered metabolism of tumour surface glycoproteins and sialoglycolipids. The higher increases observed in malignancies to controls and benign breast conditions indicate that these are sensitive specific markers for breast malignancy. The TSA and TSA/TP values have good diagnostic potential in identifying breast malignancy. The TSA/TP values are significantly higher in malignancies with distant metastasis compared to malignancies without metastasis indicating their usefulness as markers for extent of disease and tumour load. ${ }^{27}$

\section{Limitations}

Study should have been carried on a larger group of population. Another tumour marker could have been included in the study to compare with sialic acid. Benign tumours group should have been included.

\section{REFERENCES}

[1] Imran Ali, Wani WA, Saleem K, et al. Cancer Scenario in India with future perspectives. Cancer Therapy 2011;8:56-70.

[2] Chan DW, Schwartz MK. Tumor markers: introduction and general principles. In: Diamandis EP, Fritsche HA, Lilja $\mathrm{H}$, et al. eds. Tumor markers: physiology, pathobiology, technology and clinical applications. Washington, DC: AACC Press 2002:9-17.

[3] Hammond EH. Quality control and standardization for tumor markers. In: Diamandis EP, Fritsche HA, Lilja H, et al. eds. Tumor markers: physiology, pathobiology, technology and clinical applications. Washington, DC: AACC Press 2002:25-32.

[4] Schauer R. Chemistry, metabolism and biological functions of sialic acids. Adv Carbohydr Biochem 1982;40:131-234.

[5] Yogeeswaran G. Cell surface glycolipids and glycoproteins in malignant transformation. Adv Cancer Res 1983;38:289-350.

[6] Skipski VP, Carter SP, Terebus-Kekish OI, et al. Ganglioside profiles of metastases and of metastasizing and nonmetastasizing rat primary mammary carcinomas. J Natl Cancer Inst 1981;67(6): 1251-8.

[7] Yogeeswaran G, Salk PL. Metastatic potential is positively correlated with cell surface sialylation of cultured murine tumor cell lines. Science 1981;212(4502):1514-6.

[8] Yogeeswaran G, Sebastian H, Stein BS. Cell surface sialylation of glycoproteins and glycosphingolipids in cultured metastatic variant RNA-virus transformed non-producer BALB/c 3T3 cell lines. Int J Cancer 1979;24(2):193-202.

[9] Kloppel TM, Morre DJ. Characteristics of transplantable tumors induced in the rat by $\mathrm{N}$-2-fluorenylacetamide: elevations in tissue and serum sialic acid. J Natl Cancer Inst 1980;64(6):1401-11.

[10] Katopodis N, Hirshaut Y, Geller NL, et al. Lipidassociated sialic acid test for the detection of human cancer. Cancer Res 1982;42(12):5270-5.

[11] Gökmen SS, Kazezoğlu C, Tabakoğlu E, et al. Serum total sialic acid levels in lung cancer patients of different histological types with and no extrapulmonary metastases. Turk J Biochem 2004;29(4):262-7.

[12] Travingm C, Schauer R. Structure, function and metabolism of sialic acid. Cell Mol Life Sci 1998;54(12):1330-49. 
[13] Schauer R. Achievements and challenges of sialic acid research. Glycoconj J 2000;17(7-9):485-99.

[14] Black PH. Shedding from the cell surface of normal and cancer cells. Adv Cancer Res 1980;32:75-199.

[15] Kaplan J, Moskowitz M. Studies on the turnover of plasma membranes in cultured mammalian cells. II. Demonstration of heterogeneous rates of turnover for plasma membrane proteins and glycoproteins. Biochim Biophys Acta 1975;389(2):306-13.

[16] Ryan AH, Fennelly JJ. Serum sialic acid concentrations in malignant melanoma. Eur J Cancer 1981;17(7):8434.

[17] Silver HKB, Murray RN, Worth AJ, et al. Prediction of malignant melanoma recurrence by serum $\mathrm{N}$ acetylneuraminic acid. Int J Cancer 1983;31(1):39-43.

[18] Silver HKB, Karim KA, Salinas FA, et al. Significance of sialic acid and carcinoembryonic antigen as monitors of tumor burden among patients with carcinoma of the ovary. Surg Gynecol Obstetrics 1981;153(2):209-13.

[19] Hogan-Ryan A, Fennelly JJ, Jones M, et al. Serum sialic acid and CEA concentrations in human breast cancer. Br J Cancer 1980;41(4):587-92.

[20] Plucinsky MC, Riley WM, Prorok JJ, et al. Total and lipidassociated serum sialic acid levels in cancer patients with different primary sites and differing degrees of metastatic involvement. Cancer 1986;58(12):2680-5.
[21] Hamad AWR, Talabani NGA, Al-Swad F. Evaluation of lipid-bound sialic acid tumor marker in sera of acute lymphocytic (ALL) patients. J Bagh College of Dentistry 2008;20(1):28-30.

[22] Baskaran K, Satish R, Santhosh V, et al. Status of sialic acid in patients with cervical intraepithelial neoplasia and cervical carcinoma. Journal of Cell and Tissue Research 2010;10(3):2375-78.

[23] Kadam CY, Katkam RV, Suryakar AN, et al. Biochemical markers in oral cancer. Biomedical Research 2011;22(1):76-80.

[24] Patel PS, Baxi BR, Adhvaryu SG, et al. Evaluation of serum sialic acid, heat stable alkaline phosphatase and fucose as markers of breast carcinoma. Anticancer Res 1990;10(4):1071-4.

[25] Durgawale P, Sontakke A, Shukla PS, et al. Alterations in Total Sialic Acid (TSA), Total Proteins (TP) and TSA/TP ratio in cancer patients. Biomedical Research 2011;22(4):492-4.

[26] Romppanen J. Serum Sialic Acid in Clinical Diagnostics. Kuopio University Publications D. Medical Sciences 309, 2003; p. 50.

[27] Sreeramulu V, Ramana V. Evaluation of serum total and lipid associated sialic acid as a tumor marker in breast malignancy. IOSR-JPBS 2014;9(2):14-17. Ver. IV. 